\title{
A Bibliographical Approach to English Language Teaching
}

\author{
José Mateo and María José Huesca \\ Universidad de Alicante
}

\section{Introduction}

Writing up a specialized bibliography is not always easy, especially if it concerns the teaching of English - a varied and multidisciplinary field. To determine the guidelines of this task has implied many decisions and problems, difficult to make and solve. Taking into consideration the fact that, for obvious reasons, our selection has undergone several limitations, we think it proper to inform the reader about the main reasons that have guided our choice of the books shown in the following pages. In this way, he or she will understand why familiar books do not appear, while others, completely unknown to him or her, do.

First, the vast number of books published in English Language Teaching every year makes its compilation impossible. It is also unnecessary because an important percentage of the books advertised in catalogues are simple variations on the same topic. The reason they are published lies in the increasing importance given to the teaching of English as a Second Language over the past years. This constantly growing demand has forced the publishers to work overtime to quench this academic thirst. Few of these books, however, are truly innovative or offer the teacher and researcher a new perspective to be applied to his or her daily work. On the lines of these words, we have tried to include in this bibliographical selection two sets of texts. On the one hand, we have chosen books which are opening new ways in the understanding of the processes that govern the linguistic-communicative competence in English and which help to provide the necessary techniques to achieve this objective. On the other hand, we have not forgotten to mention those others that have been a landmark in the development of language teaching skills.

Secondly, the theoretical and methodological aspects covered and studied in this field are so heterogeneous that we resolved to divide our selection into four different sections. These refer to fundamental teaching points, the scientific and theoretic proposals maintained, various practical approaches in the classroom by means of studentoriented activities and a list of specialized periodicals and journals.

Finally, in accordance with what has been pointed out in the two previous paragraphs, we have refrained from writing a recommended bibliography, although we cannot escape the fact that every selection implies a certain degree of subjectivity. We 
have also tried to offer the reader a comprehensive and, at the same time, diverse selection of texts that try to summarize the huge scope of manuals devoted to the teaching of the English language. The reader himself will have to establish their pertinence and suitability to his or her line of research through academic scrutiny. That is, however, no obstacle to our firm belief that an important number of the books and texts included in this bibliography possess a high level of quality, originality and scientific rigour. They constitute, in our opinion, essential references to the present and to the past of the teaching of English and pioneering examples of this discipline's future in the coming years. The selection shown in the following pages has been organized in accordance with the classified patterns that follow:

a. In a first group or section, we include those theoretical books that become the basis of the more practical and functional lay-out of classroom teaching. This first selection ranges over books that develop both generic matters about teaching and teacher training, and the treatment of learning as a linguistic, psychological and sociological (bilingualism) mechanism.

b. The second section shows books centred on the teacher's performance in the classroom. We have chosen those texts that present useful techniques and activities in order to improve the student's knowledge of the language. They are books on the structure of English (phonetics, grammar and vocabulary) and its communicative skills (understanding, speaking, reading, writing, functions and other cultural and pragmatic uses). This section also contains books devoted to testing the progress and analyze the results derived from the teacher-student interaction in the classroom.

c. The third section presents texts related to the teaching of English for Specific Purposes (E.S.P), along with books that pose the present technological breakthroughs in this field. They tell the reader about future prospects in the use of electronic tools such as videos, computers, interactive systems, etc. Finally, other manuals concern interesting therapeutical and clinical subjects especially centred on handicapped students with psycho-motoric deficiencies (deaf, dumb, aphasic, etc.).

d. The fourth and last section offers a list of journals and periodicals specializing in the study of the aspects dealt with in (a), (b) and (c).

\section{The Theory in the Teaching of English}

Abercrombie, D. Problems and Principles in Language Study. London: Longman, 1967. Alatis, J. The Second Language Classroom. London: Oxford UP, 1981.

Alburquerque et al. En el aula de inglés. Madrid: Longman, 1990.

Alcaraz, E. and Brynn Moody. La didáctica del inglés. Madrid: Alhambra, 1983.

Allcoright, R. et al. Focus on the Language Classroom. Cambridge: Cambridge UP, 1989.

Allen, J. P. B. et al. eds. Techniques in Applied Linguistics. Oxford: Oxford UP, 1978. eds. Papers in Applied Linguistics. Oxford: Oxford UP, 1978. eds. Readings for Applied Linguistics. Oxford: Oxford UP, 1978. 
Allwright, R. L. Observation in the Language Classroom. Harlow: Longman, 1988.

Anshen, F. Statistics for Linguistics. Cambridge, Mass.: Newbury, 1978.

Archer, M. et al. English for Cambridge Proficiency. London: Nelson, 1981.

Ashworth, M. Beyond Methodology. Cambridge: Cambridge UP, 1988.

Barnes, D. et al. Language, the Learner and the School. London: Penguin, 1969.

Bestard, J. Preparación y desarrollo de las clases de inglés. Madrid: Edi-6, 1983. . La enseñanza del inglés a los niños. Madrid: Edi-6, 1985.

Bickley, U. ed. Languages in Education in a Bi-Lingual or Multi-Lingual Setting. Hong

Kong: Institute of Language in Education, 1988.

Billows, F. The Techniques of Language Teaching. London: Longman, 1968.

Blair, R. ed. Innovative Approaches to Language Teaching. Cambridge, Mass.: Newbury, 1982.

Bloomfield, L. Language. New York: Holt, 1961.

Bohlen, A. Metodología en la enseñanza de idiomas modernos. Madrid: D. G. E. M, 1963.

Bright, et al. Teaching English as a Second Language. London: Longman, 1970.

Broughton, G. et al. Teaching English as a Foreign Language. London: Routledge, 1978.

Brown, J. D. Understanding Research in Second Language Learning. Cambridge: Cambridge UP, 1989.

Brumfit, C. J. Problems and Principles in English Teaching. Oxford: Pergamon Press, 1980.

. Language and Literature Teaching: From Practice to Principle. Oxford:

Pergamon Institute of English, 1985.

et al. eds. The Communicative Approach to Language Teaching. Oxford:

Oxford UP, 1979.

Bruner, J. S. Towards a Theory of Instructions. New York: Norton, 1968.

Byrne, D. Techniques for Classroom Interaction. London: Longman, 1987.

Carrell, P. et al. eds. Interactive Approaches to Second Language Reading. Cambridge:

Cambridge UP, 1988.

Chapman, L. R. H. Teaching English to Beginners. London: Longman, 1966.

Clark, J. L. Curriculum Renewal in School Foreign Language Learning. Oxford: Oxford UP, 1987.

Close, R. A. English as a Foreign Language: Its Constant Grammatical Problems. London: George Allen, 1986.

Colin, B. Key Issues in Bilingualism and Bilingual Education. Clevedon, Avon: Multilingual Matters, 1988.

Corder, S. P. Introducing Applied Linguistics. Harmondsworth: Penguin, 1973.

Crombie, W. Discourse and Language Learning: A Relational Approach to Syllabus Design. Oxford: Oxford UP, 1985.

. Process and Relation in Discourse and Language Learning. Oxford: Oxford UP, 1985.

Currie, W. New Directions in Teaching English Language. London: Longman, 1973.

Dato, D. ed. Developmental Psycholinguistics: Theory and Applications. Washington: Washington UP, 1975.

Davies, P. et al. Situational Lesson Plans. London: Macmillan, 1975. 
Day, R. ed. Talking to Learn: Conversation in Second Language Acquisition. Cambridge, Mass.: Newbury, 1986.

Dechert, H. et al. eds. Interlingual Processes. Tübingen: Gunter Narr, 1989.

Departamento de Idiomas del Instituto Veritas. Nueva estrategia para un departamento de idioma. Madrid: Marcea, 1978.

Dickinson, L. Self-Instruction in Language Learning. Cambridge: Cambridge UP, 1988.

Diller, K. The Language Teaching Controversy. Cambridge, Mass.: Newbury, 1978.

Dixson, R. J. Practical Guide to the Teaching of English as a Foreign Language. New York: Regents, 1975.

Doff, A. Teach English. Cambridge: Cambridge University Press, 1989.

Donoghue, M. ed. Foreign Languages and the Schools: A Book of Readings. Brown, 1969.

Doyle, B. English and Englishness. London: Routledge, 1989.

Duh, T. Explorations in Teacher Training. London: Longman, 1989.

Dunn, O. Beginning English with Young Children. London: Macmillan, 1983.

Eckman, F. et al. eds. Universals of Second Language Acquisition. Cambridge: Cambridge UP, 1984.

Ellis, R. Understanding Second Language Acquisition. Oxford: Oxford UP, 1985.

Faerch, C. et al. eds. Introspection in Second Language Research. Clevedon, Avon: Multilingual Matters, 1987.

Ferguson, N. Teaching English as a Foreign Language: Theory and Practice. Lausanne: Didier International, 1972.

Finocchiaro, M. et al. The Foreign Language Learner. New York: Regents, 1973. . English as a Second Language. New York: Regents, 1974.

Fisiak, J. ed. Contrastive Linguistics and the Language Teacher. Oxford: Pergamon Institute of English, 1985.

Fraser, H. et al. eds. Applied Linguistics and the Teaching of English. London: Longman, 1973.

Gantie, , H. La enseñanza de idiomas. Madrid: Marova, 1972.

Gardener, R. C. et al. Attitudes and Motivation in Second-language Learning. Cambridge, Mass.: Newbury, 1972.

Gass, S. ed. Variation in Second Language Acquisition. Clevedon, Avon: Multilingual Matters, 1989.

et al. eds. Linguistic Perspectives on Second Language Acquisition. Cambridge: Cambridge UP, 1990.

Genesse, F. Learning Through two Languages: Studies of Immersion and Bilingual Education. New York: Newbury, 1987.

Gougher, L. et al. eds. Individualization of Instruction in Foreign Languages: A Practical Guide. Philadelphia: C. C. D., 1972.

Grant, N. Making the Most of your Textbook. London: Longman, 1987.

Gurrey, P. Teaching English as a Foreign Language. London: Longmans, 1969.

Hamers, J. F. et al. Bilinguality and Bilingualism Matters. Cambridge: Cambridge UP, 1989.

. The Practice of English Language Teaching. London: Longman, 1983.

Hawkins, E. Modern Languages in the Curriculum. Cambridge: Cambridge UP, 1981.

Heaton, J. B. Studying in English. London: Longman, 1975. 
Hill, L. A. Selected Articles of the Teaching of English as a Second Language. London:

Oxford UP, 1967. et al. A Teacher Training Course. London: Cassell, 1979.

Holden, S. ed. Teacher Training. Manfield: Modern English Publications, 1979.

Hornsey, A. Handbook for Modern Language Teachers. London: Methuen, 1975.

Howard, B. et al. eds. Individualizing Foreign Language Instruction. Cambridge, Mass.: Newbury, 1971.

Howatt, A. P. R. A History of English Language Teaching. Oxford: Oxford UP, 1984.

Hughes, G. S. A Handbook of Classroom English. Oxford: Oxford UP, 1981.

Hyltenstam, K. et al. eds. Modelling and Assessing Second Language Acquisition.

Clevedon, Avon: Multilingual Matters, 1985. eds. Bilingualism across the Lifespan. Cambridge: Cambridge UP, 1989.

Jakobovits, L. Learning Foreign Language: A Psycholinguistic Analysis of the Issues. Cambridge, Mass.: Newbury, 1971. et al. The Context of Foreign Language Teaching. Cambridge, Mass.: Newbury, 1974.

James, A. et al. eds. New Linguistic Impulses in Foreign Language Teaching. Tübingen:

Gunter Narr, 1981.

Janicki, K. The Foreigner's Language. Oxford: Pergamon, 1985.

Johnson, K. ed. The Second Language Curriculum. Cambridge: Cambridge University Press, 1989. et al. eds. Communication in the Classroom. London: Longman, 1981. et al. eds. Perspectives in Communicative Language Teaching. London: Academic Press, 1983.

Johnstone, R. Communicative Interaction: a Guide for Language Teachers. London: CILT, 1989.

Jones, M. et al. eds. Learning me your Language: Perspectives on the Teaching of English. London: Mary Glasgow, 1987.

Keen, J. Teaching English: A Linguistic Approach. London: Methuen, 1978.

Kennedy, C. ed. Language Planning and English Language Teaching. London: Prentice-Hall International, 1989.

Kinsella, V. ed. Language Teaching and Linguistics: Surveys. Cambridge: Cambridge UP, 1978. ed. Surveys 1: Eight State-of-the-art Articles on Key Areas in Language Teaching. Cambridge: Cambridge UP, 1982.

Knibbeler, W. et al. New Approaches in Foreigr Language Methodology. 15th AIMAV Colloquium. Brussels: AIMAV, 1986.

Krashen, S. D. Second Language Acquisition and Second Language Learning. Oxford: Pergamon Press, 1981. . Principles and Practice in Second Language Acquisition. Oxford: Pergamor: Press, 1982. . The Input Hypothesis: Issues and Implications. Oxford: Pergamon Press, 1983. et al. The Natural Approach: Language Acquisition in the Classroom. Oxford:

Pergamon Press, 1983.

Lado, R. Language Teaching. New York: McGraw-Hill, 1964. . Linguistics Across Cultures. U of Michigan P, 1980.

Laird, E. English in Focus: English in Education. Oxford: Oxford UP, 1979. 
Larsen-Freeman, D. Techniques and Principles in Language Teaching. Oxford: Oxford UP, 1986.

ed. Discourse Analysis in Second Language Research. Cambridge, Mass.:

Newbury, 1980.

Leeson, R. Fluency and Language Teaching. London: Longman, 1975.

Lemke, J. L. Using Language in the Classroom. Oxford: Oxford UP, 1989.

Linguistic Theories and their Application. Consejo de Europa, 1967.

Littlewood, W. Communicative Language Teaching. Cambridge: Cambridge UP, 1981.

Lugton, R. C. et al. eds. Preparing the E. F. L. Teacher: A Projection for the '70's. Philadelphia: C. C. D., 1970.

Lugton, R. C. et al, eds. Toward a Cognitive Approach to Second Language Acquisition. Philadelphia: C. C. D., 1971.

Mackey, W. Language Teaching Analysis. Bloomington: Indiana UP, 1975.

Malamah-Thomas, A. Classroom Interaction. Oxford: Oxford UP, 1987.

Maley, A. et al. eds. Mind Matters. Cambridge: Cambridge UP, 1981.

Martín Gamero, S. La enseñanza del inglés en España. Madrid: Gredos, 1961.

McLaughlin, B. Theories of Second-Language Learning. London: Edward Arnold, 1987.

Michael, I. The Teaching of English from the Sixteenth Century to 1870. Cambridge:

Cambridge UP, 1987.

Monroig, B. La didáctica de la lengua inglesa. Madrid: Edi-6, 1982.

Morris, J. Language in Action: Resource Book. London: Macmillan, 1980.

Munby, J. Communicative Syllabus Design. Cambridge: Cambridge UP, 1978.

Nash, R. Teacher Expectations and Pupil Learning. London: Routledge, 1976.

Nunan, D. The Learner-Centred Curriculum. Cambridge: Cambridge UP, 1988.

O'Malley, J. M. et al. Learning Strategies in Second Language Acquisition. Cambridge: Cambridge UP, 1989.

Ogden, C. K. Basic English: a General Introduction. London: Kegan Paul, Trench \& Trubner, 1930.

Oller, J. et al. eds. Focus on the Learner: Pragmatic Perspectives for the Language Teachers. Mass.: Newbury, 1973.

Ornstein, J. et al. Programmed Instructions and Educational Technology in the Language Teaching Field. Philadelphia: C. C. D., 1971.

Palmer, A. et al. The Listening Approach: Applying The Input Hypothesis. London: Longman, 1983.

Parkinson, S. La lingüística y la enseñanza de las lenguas: teoría y práctica. Madrid: Empeño 14, 1980.

Pérez Martín, M. J. Hacia una integración de las disciplinas de lengua y literatura inglesas. Madrid: Aguilar, 1978.

Pfaff, C. W. ed. First and Second Language Acquisition Processes. Cambridge, Mass.: Newbury, 1987.

Pietro, R. Strategic Interaction. Cambridge: Cambridge UP, 1988.

Prabhu, N. Second Language Pedagogy. Oxford: Oxford UP, 1987.

Preston, D. R. Sociolinguistics and Second Language Acquisition. Oxford: Blackwell, 1989.

Protherough, R. Students of English. London: Routledge, 1989.

Renard, et al. Foreign Language Teaching with an Integrated Methodology: The

S. G. A. V. Paris: Didier, 1976. 
Richard-Amato, P. A. Making it Happen: Interaction in the Second-Language Classroom: From Theory to Practice. London: Longman, 1988.

Richards, J. C. ed. Understanding Second and Foreign Language Learning: Issues and Approaches. Cambridge, Mass.: Newbury, 1978.

Richards, J. C. et al. Approaches and Methods in Language Teaching. Cambridge: Cambridge UP, 1988.

Riley, P. ed. Discourse and Learning. London: Longman, 1985.

Rivers, W. Speaking in Many Tongues: Essays in Foreign-language Teaching. Rowley, Mass.: Newbury, 1972.

. A Practical Guide to the Teaching of English. Chicago: U of Chicago P, 1981. ed. Interactive Language Teaching. Cambridge: Cambridge UP, 1987. et al. A Practical Guide to the Teaching of English. New York: Oxford UP, 1978.

et al. eds. Changing Patterns in Foreign Language Programs. Cambridge, Mass.: Newbury, 1972.

Robinson, J. An Annotated Bibliography of Modern Language Teaching. Oxford: Oxford UP, 1969.

Rodríguez, F. et al. Didáctica de la lengua Inglesa. Barcelona: Humanitas, 1985.

Romaine, S. Bilingualism. Oxford: Blackwell, 1989.

Roulet, E. Linguistic Theory, Linguistic Description and Language Teaching. London: Longman, 1973.

Rutherford, W. E. Second Language Grammar: Learning and Teaching. Harlow: Longman, 1987.

Sánchez, A. La enseñanza de idiomas. Barcelona: Hora, 1982.

Siles, J. et al. Didáctica del Inglés. Murcia: Libros-Beniaján, 1977.

Sinclair, J. M. et al. Towards an Analysis of Discourse: The English Used by Teachers and Pupils. Oxford: Oxford UP, 1975. et al. Teacher Talk. Oxford: Oxford UP, 1982.

Skehan, P. Individual Differences in Second-language Learning. London: Edward Arnold, 1989.

Smith, P. D. A Comparison of the Cognitive and Audiolingual Approaches to Foreign Language Instruction. Philadelphia: C. C. D., 1970.

Spolsky, B. Educational Linguistics. Cambridge, Mass.: Newbury, 1969.

ed. Language \& Education in Multilingual Settings. Clevedon: Multilingual

Matters, 1986.

Spolsky, B. Conditions for Second Language Learning. Oxford: Oxford UP, 1989.

Steiner, F. Performing with Objectives. Cambridge, Mass.: Newbury, 1975.

Stern, H. H. Fundamental Concepts of Language Teaching. Oxford: Oxford UP, 1983. ed. Languages and the Young School Child. Oxford: Oxford UP, 1969.

Strenski, E. et al. The Research Paper Workbook. New York: Longman, 1981.

Strevens, P. Papers in Language and Language Teaching. London: Oxford UP, 1965. . New Orientations in the Teaching of English. Oxford: Oxford UP, 1978.

Stubbs, M. Language, Schools and Classrooms. London: Methuen, 197.6.

Sweet, H. The Practical Study of Languages. Oxford: Oxford UP, 1972.

. The Practical Study of Language: a Guide for Teachers and Learners.

London: Dent; rpt. Oxford UP, 1899. 
Talden, J. Principles of Course Design for Language Teaching. Cambridge: Cambridge UP, 1988.

Tarone, E. et al. Focus on the Language Learner. Oxford: Oxford UP, 1989.

Teaching Language as Communication. Barcelona: Institut de Ciéncies de l'Educació, 1983.

Tinkel, A. J. Explorations in Language. Cambridge: Cambridge UP, 1988.

Van Patten, B. et al. eds. Foreign Language Learning: a Research Perspective. New York: Newbury, 1987.

Van Ek, J. A. The Threshold Level for Modern Language Learning in Schools. London: Longman, 1976. 1975 . et al. Threshold Level English. Oxford: Pergamon for the Cuncil of Europe, et al. Waystage English. Oxford: Pergamon Press, 1980.

Van Lier, L. The Classroom and the Language Learner. Harlow: Longman, 1988.

Walker, R. et al. A Guide to Classroom Observation. London: Methuen, 1975.

Wardhaugh, R. Topics in Applied Linguistics. Cambridge, Mass.: Newbury, 1975.

Wenden, A. et al. Learner Strategies in Language Learning. New York: Prentice-Hall International, 1987.

White, R. The ELT Curriculum. Oxford: Basil Blackwell, 1988.

Widdowson, H. G. Teaching Language as Communication. Oxford: Oxford UP, 1978. . Explorations in Applied Linguistics. Oxford: Oxford UP, 1979.

Wilkins, D. A. Linguistics in Language Teaching. London: Arnold, 1975. Notional Syllabuses. London: Oxford UP, 1976. . Second-language Learning and Teaching. London: Edward Arnold, 1981.

Williams, F. Explorations of the Linguistic Attitudes of Teachers. Cambridge, Mass.: Newbury, 1978.

Willis, J. Teaching English Through English. Harlow: Longman, 1983.

Winter, E. Towards a Contextual Grammar of English. London: George Allen, 1982.

Wright, T. Roles of Teachers and Learners. Oxford: Oxford UP, 1987.

Wringe, C. The Effective Teaching of Modern Languages. Harlow: Longman, 1989.

Yalden, J. Principles of Course Design for Language Teaching. Cambridge: Cambridge UP, 1987.

\section{The Practice in the Teaching of English}

Abbs, B. Realistic English Dialogues. London: Oxford UP, 1978. Abercrombie, D. English Phonetic Texts. London: Faber, 1964.

Alcaraz, E. and Brynn Moody. Morfoxintasis inglesa para hispanohablantes. Alcoy: Marfil, 1980.

Alcaraz, E. and Brynn Moody. Fonética inglesa para españoles. Alcoy: Marfil, 1984. Alcaraz, E. and J. Ramón. La evaluación del inglés. Madrid: S.G.E.L., 1980.

Alderson, J. C. et al. Issues in Language Testing. London: The British Council, 1981. Altman, H. B. et al. Essays on the Teaching of Culture. Detroit: Advancement Press of America, 1974.

Anderson, A et al. Listening. Oxford: Oxford UP, 1988. 
Arndt, H. et al. An Ordered Inventory of Communicative Functions for General Foreign Language Teaching. Aarhus: Aarhus UP, 1986.

Baker, A. Ship or Sheep and Tree or Three. Cambridge: Cambridge UP, 1977.

Black, C. A Handbook of Free Conversation. London: Oxford UP, 1970.

Bradford, B. Intonation in Context. Cambridge: Cambridge UP, 1988.

Brooker, P. et al. eds. Dialogue and Difference: English into the Nineties. London:

Routledge, 1989.

Brookes, A. et al. Writing for Study Purposes. Cambridge: Cambridge UP, 1989.

Brown, G. et al. Teaching The Spoken Language. London: Cambridge UP, 1983.

Brumfit, C. J. Language and Literature Teaching: From Practice to Principle. Oxford:

Pergamon, 1985.

et al. Literature \& Language Teaching. Oxford: Oxford UP, 1986.

Bygate, M. Speaking. Oxford: Oxford UP, 1987.

Carroll, B. J. Testing Communicative Performance. London: Pergamon, 1978.

et al. Make Your Own Language Test: A Practical Guide to Writing Language

Performance Tests. Oxford: Pergamon, 1985.

et al. The Web of Words. Cambridge: Cambridge UP, 1987.

et al. Vocabulary and Language Teaching. London: Longman, 1988.

et al. Literature \& the Learner: Methodological Approaches. London: The

British Council, 1989.

Collie, J. et al. Literature in the Language Classroom. Cambridge: Cambridge UP, 1987.

Cooper, C. et al. Evaluating Writing. Illinois: NCTE, 1977.

Corson, D. Oral Language across the Curriculum. Clevedon, Avon: Multilingual Matters, 1988.

Cunmingsworth, A. Evaluating and Selecting EFL Materials. London: Heinemann, 1984.

Dean, M. Write It. Cambridge: Cambridge UP, 1988.

Dougill, J. Drama Activities for Language Learning. Basingstoke: Macmillan, 1987.

Dubin, F. et al. eds. Teaching Second Language Reading for Academic Purposes.

Reading, Mass.: Addison-Wesley, 1986.

et al. Reading on Purpose. Reading, Mass.: Addison-Wesley, 1987.

Hill, J. Using Literature in Language Teaching. Basingstoke: Macmillan, 1987.

Edge, J. Mistakes \& Correction. London: Longman, 1989.

Eynon, J. Multiple Choice Questions in English. London: Hamish-Hamilton, 1974.

Frank, C. et al. Grammar in Action. Munich: Hueber, 1983.

Gairns, R. et al. Working with Words: A Guide to Teaching and Learning Vocabulary.

New York: Cambridge UP, 1986.

Gimson, A. C. A Practical Course of English Pronunciation. London: Edward Arnold, 1975.

. An Introduction to the Pronunciation of English. London: Edward Arnold, 1980.

Gower, R. et al. Reading Literature. London: Longman, 1986.

Grupo Eledos. De dos en dos. Madrid: Longman, 1990.

Halliday, M. A. K. Spoken and Written Language. Oxford: Oxford UP, 1989.

Harmer, J. Teaching and Learning Grammar. London: Longman, 1987.

Harris, D. Testing English as a Second Language. New York: McGraw-Hill, 1969. 
Haycraft, B. The Teaching of Pronunciation. London: Longman, 1970.

Heaton, J. B. Writing English Languages Tests. London: Longman, 1975. Classroom Testing. London: Longman, 1989.

Hedge, T. Using Readers in Language Teaching. London: MacMillan, 1985.

Henning, G. A. Guide to Language Testing: Development, Evaluation, Research. New York: Newbury, 1987.

Hill, L. A. English Language Teaching Games. London: Evans, 1970.

Hirasawa, L. et al. Developing Reading Skills: Advanced. Cambridge, Mass.: Newbury, 1975.

Hooke, R. et al. A Handbook of English Pronunciation. London: Arnold, 1982.

Hughes, A. Testing for Language Teachers. Cambridge: Cambridge UP, 1989.

Ilson, R. ed. Dictionaries, Lexicography and Language Learning. Oxford: Pergamon

Press., 1985.

Jerran, et al. Conversation Exercises in Everyday English. London: Longman, 1965.

Jones, D. The Pronunciation of English. London: Cambridge UP, 1956.

Jones, L. Functions of English. Cambridge: Cambridge UP, 1977. . Notions in English. Cambridge: Cambridge UP, 1979. Ideas: Speaking and Listening Activities for Upper-Intermediate Studentes.

Cambridge: Cambridge UP, 1984.

Harmer, J. et al. Advanced Speaking Skills. London: Longman, 1980.

Keidler, C. W. The Pronunciation of English. London: Blackwell, 1989.

Kenworthy, J. Teaching English Pronunciation. London: Longman, 1987.

Knowles, G. Patterns of Spoken English: An Introduction to English Phonetics. London: Longman, 1987.

Kroll, B. M. et al. Explorations in the Development of Writing. Chichester: John Wiley, 1983.

Lado, R. Language Testing. London: Longman, 1961.

Ladousse, G. Speaking Personally. Cambridge: Cambridge UP, 1983. . Role Play. Oxford: Oxford UP, 1987.

Lancaster, G. et al. Working with Children's Phonology. Winslow Press, 1989.

Lee, W. R. Language Teaching Games and Contests. London: Oxford UP, 1979.

Little, D. et al. Learning Foreign Languages from Authentic Texts: Theory and Practice. London: Authentik-CILT, 1989.

Livingstone, C. Role Play in Language Learning. London: Longman, 1983.

Loup, G. et al. eds. Interlanguage Phonology: The Acquisition of a Second Language

Sound System. Cambridge, Mass.: Newbury, 1987.

Madsen, H. Techniques in Testing. Oxford: Oxford UP, 1983.

Maley, A. et al. Drama Techniques in Language Learning. Cambridge: Cambridge UP, 1978.

Markstein, L. et al. Expanding Reading Skills: Advanced. Cmbridge, Mass.: Newbury, 1977.

McKeown, M. et al. eds. The Nature of Vocabulary Acquisition. Hillsdale, N.J.: Lawrence Earlbaum, 1987.

McRae, J. et al. Reading Between the Lines. Cambridge: Cambridge UP, 1984.

Meara, P. Vocabulary in a Second Language: Specialised Bibliography, 3. London:

CILT, 1983.

Merrill Valdes, J. Culture Bound. Cambridge: Cambridge UP, 1987. 
Monroy, R. La pronunciación del inglés R.P. para hablantes de español. Madrid: Paraninfo, 1980.

Moody, H. L. B. The Teaching of Literature. London: Longman, 1971.

Morgan, J. et al. Vocabulary. Oxford: Oxford UP, 1987.

Morrow, K. Techniques of Evaluation for a Notional Syllabus. Reading: Centre for Applied Language Studies of the U of Reading, 1977.

Murphy, M. J. Test Yourself on English Idioms. London: Hodder and Stoughton, 1981. Musman, R. et al. Britain Today. London: Longman, 1989.

Nolasco, R. et al. Conversation. Oxford: Oxford UP, 1987.

Nunan, D. Designing Tasks for the Communicative Classroom. Cambridge: Cambridge UP, 1989.

Nuttall, C. Teaching Reading Skills in a Foreign Language. London: Heinemann. 1982. O'Connor, J. D. Better English Pronunciation. Cambridge: Cambridge UP, 1980.

Oller, J. Language in Education: Testing the Tests. Cambridge, Mass.: Newbury, 1979. Prator, C. et al. Manual of American English Pronunciation. New YorK: Holt, 1985. Quirk, Randolph et al. A University Grammar of English. London: Longman, 1976. Raimes, A. Techniques in Teaching Writing. New York: Oxford UP, 1983.

Rinvolucri, M. Grammar Games. Cambridge: Cambridge UP, 1984.

Rixon, S. Developing Listening Skills. London: MacMillan, 1986.

Rudska, B. et al. The Words you Need. London: Macmillan, 1981. et al. More Words You Need. London: Macmillan, 1985.

Schrampher-Azar, B. Understanding and Using English Grammar. New York: PrenticeHall, 1989.

Seelye, H. N. Teaching Culture: Strategies for Foreign Language Educators. National Textbook, 1974.

Somaratne, W. R. P. Aids and Tests in the Teaching of English. Oxford: Oxford UP, 1969.

Spencer, D. H. English Conversation Practice. Madrid: Mangold, 1968.

Stuart, D. D. Feeling and Judging in English. London: Oxford UP, 1969.

Swan, M. Practical English Usage. London: Oxford UP, 1980.

Tannen, D. Talking Voices: Repetition, Dialogue and Imagery in Conversational Discourse. Cambridge: Cambridge UP, 1989.

Thomson and Martinet. A Practical English Grammar. London: Oxford UP, 1975.

Thornton, G. Teaching Writing: The Development of Written Language Skills. London: Edward Arnold, 1980.

Tomlinson, B. Openings. London: Lingual House, 1986.

Underhill, N. Testing Spoken Language. Cambridge: Cambridge UP, 1987.

Underwood, M. Teaching Listening. Harlow: Longman, 1989.

Ur, P. Grammar Practice Activities. Cambridge: Cambridge UP. 1988.

. Teaching Listening Comprehension. Cambridge: Cambridge UP, 1984.

Tribble, C. et al. Using Concordances in the Classroom. London: Longman, 1989.

Weir, C. Communicative Language Testing. Exeter: U. of Exeter, 1988.

Wells, J.C. Accents of English. Cambridge: Cambridge UP, 1982.

Wessels, C. Drama. Oxford: Oxford UP, 1987.

Widdowson, H. G. Stylistics and the Teaching of Literature. London: Longman, 1975.

Worrall, A. J. English Idioms for Foreign Students. London: Longman, 1975.

Wright, A. Pictures for Language Learning. London: Cambridge UP, 1989. 


\section{Specificity and Technology in the Teaching of English}

Ahmad K. et al. Computers, Language Learning and Language Teaching. London:

Cambridge UP, 1985.

Brumfit, C. et al. eds. Computers in English Language Teaching. Oxford: Pergamon, 1985.

Byrne, D. Wall Pictures for Language Practice. London: Longman, 1976.

Byrne, D. Using the Magnetboard. London: George Allen, 1980.

Cameron, K. C. ed. Computer Assisted Language Learning-Program Siructure and Principles. Oxford: Blackwell, 1989.

Coleman, J. A. ed. The Interactive Videodisc in Language Teaching. New Alyth: Lochee, 1987.

Coppen, H. Utilización didáctica de los medios audiovisuales. Madrid: Anaya, 1978.

Dakin, J. The Language Laboratory and Language Learning. London: Longman, 1973.

Davies, G. et al. Computers, Language and Language Learning. London: Centre for Information on Language Teaching Research, 1982.

El-Araby, S. Audio-Visual Aids for Teaching English: An Introduction to Materials and Methods. London: Longman, 1974.

Geddes, M. et al. eds. Video in the Language Classroom. London: Heinemann, 1982.

Hainline, D. ed. New Developments in Call. London: Croom Helm, 1987.

Harper, D. ed. E. S. P. for the University. Oxford: Pergamon Press, 1986.

Hill, B. Making the Most of Video. London: C. I. C. T., 1989.

Hutchinson, T. et al. English for Specific Purposes: A Learning-Centred Approach. Cambridge: Cambridge UP, 1987.

Jung, U. O. H. Computers in Applied Linguistics and Language Teaching: A CALL Handbook. Berne: Peter Lang, 1988.

Kennedy, C. et al. English for Specific Purposes. London: MacMillan, 1984.

Lamérand, R. Teorías de la enseñanza programada y laboratorios de idiomas. Madrid: Fragua, 1971.

Last, R. Language Teaching and the Microcomputer. Oxford: Blackwell, 1984.

Lee, W. R. et al. Simple Audio Visual Aids to Foreign Language Teaching. London: Oxford UP, 1979.

Lonesgam, J. Video in Language Teaching. London: Cambridge UP, 1988.

Mallas Casas, S. Técnicas y recursos audiovisuales. Barcelona: Oikos-tau, $197 \%$.

McDonough, J. E. S. P. in Perspective a Practical Guide. London: Collins, 1984.

McGovern, J. ed. Video Applications in English Language Teaching. Oxford: Pergamon, 1983.

Mugglestone, P. Planning and Using the Blackboard. London: George Allen, 1980.

National Council for Educational Technology. Learning Languages with Technology. Coventry: MESU, 1988.

O'Shea, T. Learning and Teaching with Computers. Brighton: Harvester, 1983.

Pennington, M. C. ed. Teaching Languages with Computers. London: Athelstan, 1989.

Rahtz, S. ed. Information Technology in the Humanities: Tools, Techniques and Applications. Chichester: Ellis Horwood, 1987.

Richards, I. A. et al. English through Pictures Book II and a Second Workbook of English. New York: Pocket Books, 1973. 
Smith, W. ed. Modern Technology in Foreign Language Education: Application and Projects. Lincolnwood, Ill.: National Textbook, 1988.

Stack, E. The Language Laboratory and Modern Language Teaching. Oxford: Oxford UP, 1971.

Stempleski, S. et al. Video in Action: Recipes for Using Video in Language Teaching. Hemel: Prentice-Hall International, 1990.

Strong, M. Language Learning \& Deafness. Cambridge: Cambridge UP, 1989.

Swales, J. Episodes in E. S. P. Oxford: Pergamon, 1988.

Tomalin, B. Video, TV and Radio in the English Class. London: Macmillan, 1980.

Trimble, L. E. S. P.: A Discourse Approach. Cambridge: Cambridge UP, 1985. . English for Science and Technology. Cambridge: Cambridge UP, 1986.

Turner, ed. Using the Language Laboratory. London: University of London, 1968. ed. Programming for the Language Laboratory. London: University of London P., 1968.

Underwood, J. H. Linguistics Computers and the Language Teacher: A Communicative Approach. Rowley, Mass.: Newbury, 1984.

Wisbey, R. A. ed. The Computer in Literary and Linguistic Research. Cambridge: Cambridge UP, 1971.

Zettersten, A. New Technologies in Language Learning. Oxford: Pergamon Press, 1986.

\section{Specialized Journals in the Teaching of English}

Anglo-American Studies. Salamanca.

Annual Review of Applied Linguistics. California: University of Southern California. Applied Linguistics. Oxford: Oxford UP.

British Journal of Disorders of Communication. London: College of Speech Therapists. CALICO Journal (Computer Aided Language Learning and Instruction Consortium).

Provo, Utah: Brigham Young University.

English for Specific Purposes: An International Journal. New York.

English Language Teaching Journal. Oxford: Oxford UP.

English Teaching Forum. Washington: United States Information Agency.

English Today. Cambridge: Cambridge UP.

Foreign Language Annals. New York: American Council on the Teaching of Foreign

Languages.

Forum (National Clearinghouse for Bilingual Education). Rosslyn, Virginia.

IRAL: International Review of Applied Linguistics in Language Teaching. Heildelberg:

University of Heidelberg.

Journal of Multilingual and Multicultural Development. Clevedon, Avon.

Journal of Research in Reading. Leeds: United Kingdom Reading Association.

Language Learning: a Journal of Applied Linguistics: Ann Arbor, Mich.: University of

Michigan.

Language Teaching. Cambridge. Cambridge UP.

Language Testing. London: Edward Arnold.

Language Testing Update. Lancaster: IELE, University of Lancaster.

Language Training. London: Language Training Services.

Modern English Teacher. London: International House. 
Practical English Teaching. London: Mary Glasgow.

Reading in a Foreign Language. Oxford: College of St. Mark and St. John, Plymouth. Research in the Teaching of English. Urbana, Ill.: National Council of Teachers of English.

Revista Alicantina de Estudios Ingleses. Alicante: Universidad de Alicante.

Second Language Research. London: Edward Arnold.

Studies in Second Language Acquisition. Bloomington, Indiana: Indiana University Linguistics Club.

System: A Journal of Educational Technology and Language Learning Systems. London: Pergamon Press.

Tesol Quarterty. Washington: Teachers of English to Speakers of Other Languages Organization. 